(C) Elsevier Scientific Publishing Company, Amsterdam - Printed in The Netherlands

\title{
THE ACTION OF A BINARY NONIONIC DETERGENT ON A KIDNEY MEMBRANE FRACTION
}

DONALD M. I'OSTER, CHARLES F. HAWKINS, DANIEL FIFE and JOHN A. JACQUEZ

Department of Physiology, School of Medicine, University of Michigan, Ann Arbor, Mich. 48104 (U.S.A.)

(Received Oct'sber 20th, 1975)

(Revision rece ived February 24 th, 1976)

(Accepted March 5th, 1976)

\section{SUMMARY}

The dismuption of a kidney cortex microsomal membrane preparation by a binary, nonionic detergent, was followed by using as markers, the changes in total protein content, and $\left(\mathrm{Na}^{+}, \mathrm{K}^{+}\right)$-ATPase in a supernatant fraction. Both markers responded similarly to changes in $\mathrm{pH}$, microsome concentration and detergent concentration, but responded differently for time-dependent studies. The $\left(\mathrm{Na}^{+}, \mathrm{K}^{+}\right)$-ATPase activity was increased 2.2 -fold ( $76.1 \mu$ moles $\mathrm{P}_{\mathrm{i}} / \mathrm{mg}$ protein $/ \mathrm{h}, 95 \%$ ouabain-sensitive) by a single detergent treatment and 3.5 fold (92\% cuabain-sensitive) by a sequential detergent treatment. Changes in the critical micelle concentration (cmc) were observed for varying detergent and protein concentrations, which suggest interactions of monomeric detergent with the membrane. The peak of $\left(\mathrm{Na}^{+}, \mathrm{K}^{+}\right)$-ATPase activity occurred above the cmc which suggests the participation of micelles in releasing the enzyme from the membranes. Hill plots of the protein released as the detergent concentration was varied showed a change in the slope near the $\mathrm{cmc}$ indicating a four-fold increase in the binding of detergent to membranes as the detergent concentration is increased above the cmc. These results suggest that the disruption of membranes by detergent involves the binding of deter-

Present addresses: (D.M.F.) Toxicology Research Laboratory, Minneapolis Veterans Hospital, 54th Street and 48th Ave. So., Minneapolis, Minn. 55417, and Department of Laboratory Medicine and Pathology, University of Minnesota Medical School, Minneapolis, Minn. 55455. To whom correspondence should be addressed at the V A. Hospital; (C.F.H.) Dep artment of Electrical Engineering and Computer Science, University of New Mexico, Albıquerque, N.M. 87131; (D.F.) Department of Pediatrics, Medical School, University of Minnesota, Minneapolis, Minn. 55455 (U.S.A.).

Abbreviatior s: cmc, critical micelle concentration; DOC, deoxycholate; LOC, Liquid Or. ganic Compcund; SDS, sodium dodecyl sulfate. 
gent monomers to the membrane followed by the formation of co-micelles of the detergent with segments of the membrane to complete the separation process.

\section{INTRODUCTION}

Detergents are used widely to disrupt cellular membranes and separate membrane enzymes and structural components [1-7]. However, in this context, optimal conditions of treatment, such as temperature, $\mathrm{pH}$, ietergent and protein concentration, time of treatment, etc. must be specifically established to achieve optimal separation of any given component from a membrane.

The present study examines the detergent optimization problem for a nonionic binary detergent acting upon a beef kidney cortex microsomal membrane preparation. In this study we used $\left(\mathrm{Na}^{+}, \mathrm{K}^{+}\right)$-ATPase as a marker, and sought to maximize its specific activity by varying the ionic strength, temperature, $\mathrm{pH}$ and time of reaction at different detergent concentrations. The amount of protein released from the membranes into the supernatant fluid of a centrifuged preparation was also moritored and used as an additional marker to follow the course of the detergent action. Selected conditions were chosen and controlled to observe the effects of varying both the detergent and protein concentrations in the reaction media. Since, to our knowledge, no biochemical studies have been reported for LOC, specific differences and similarities between our results and certain other detergent-membrane or detergent-protein studies are discussed. The results are interpreted in terms of current models of both membrane structure and detergent action on biomembranes.

\section{MATERIALS AND METHODS}

Membrane preparation. The method of preparation of the microsomal fraction from beef kidney cortex is shown in Table I which is a modification of the method of Neville [8] for preparing plasma membranes from rat liver. The kidneys were obtained from freshly slaughtered cattle at a local packing house and used immediately.

Detergent. A binary nonionic detergent, manufactured by the Amway Corporation (Ada, Michigan) called Liquid Organic Compound (LOC) was used in treating the microsomal fraction. The detergent is composed of a diethanolamide and polyoxyethylene alcohol.

Protein and enzyme activity assays. The $\left(\mathrm{Na}^{+}, \mathrm{K}^{+}\right)$-ATPase was assayed as described by Post and Sen [9] in $50 \mathrm{mM}$ Tris -acetate buffer, $\mathrm{pH} 7.2$, and the protein according to the procedure of Lowry et al. [10]. Controls with 1 $\mathrm{mM}$ ouabain were determined simultaneously, and $\left(\mathrm{Na}^{+}, \mathrm{K}^{+}\right)$-ATPase refers to the ouabain-sensitive activity. 


\section{TABLE I}

FLOW CHART OF METHOD OF PREPARATION OF MICROSOMAL FRACTION FROM BEEF KIDNEY CORTEX

Beef kidney cortex (115 g) homogenized in a Waring Blender for $2 \mathrm{~min}$ in $600 \mathrm{ml}$ of 250 $\mathrm{mM}$ sucrose. To prevent overheating the blending was done in 15-s periods alternating with $45 \mathrm{~s}$ of chilling in an ice bath.

Homogenate brought up to 11 with $50 \mathrm{mM}$ sucrose and centrifuged at $1000 \mathrm{~g}$ for $10 \mathrm{~min}$

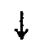

Supernatant

$\downarrow$

$150 \mathrm{ml}$ of supernatant was layered over $100 \mathrm{ml}$ of sucrose $(\mathrm{d} \mathrm{1.18})$ in each of six centrifuge buckets and spun for $90 \mathrm{~min}$ at $34000 \mathrm{~g}$.

$\downarrow$

$40 \mathrm{ml}$ of material was removed from each bucket at the interface of the sucrose (d 1.18) and the overlayed supernatant. Material from the six buckets was collected, homogenized in a loose-fitting Dounce homogenizer, and brought to $1500 \mathrm{ml}$ with $5 \mathrm{mM}$ Tris- $\mathrm{HCl}$, pH 7.2.

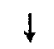

Centrifuged at $34000 \mathrm{~g}$ for $1 \mathrm{~h}$. Supernatant discarded.

$\downarrow$

Pellet resuspended in a Dounce homogenizer in $5 \mathrm{mM}$ Tris- $\mathrm{HCl}, \mathrm{pH} \mathrm{7.2,} \mathrm{to} 11$.

$\downarrow$

Centrifuged at $34000 \mathrm{~g}$ for $1 \mathrm{~h}$. The pellet was collected, homogenized, and stored in 7.5 $\mathrm{mM}$ Tris-acetate at $\mathrm{pH} 7.2,2 \mathrm{mM} \mathrm{Na}{ }_{2}$ EDTA, $1 \mathrm{mM}$ dithiothreitol and $20 \%$ glycerol at a protein concentration of $4.8 \mathrm{mg} / \mathrm{ml}$. This was used as the active microsomal fraction. The yield was about $10 \mathrm{mg}$ of protein per gram fresh weight of cortex material. This fraction could be stored at $-20^{\circ} \mathrm{C}$ for up to 2 months without significant loss of activity.

Control experiments showed that the inclusion of LOC at concentrations from $0.1 \%$ to $0.55 \%$ in the $\left(\mathrm{Na}^{+}, \mathrm{K}^{+}\right)$-ATPase assay of untreated microsomes did not affect the activity. When $100 \mu \mathrm{g}$ protein was present in $0.1 \% \mathrm{LOC}$ during the Lowry protein assays, the detergent did not interfere with the color development. This ratio, or greater, of protein to detergent was maintained for the protein assays. The conditions for $P_{i}$ estimation were such that various treatments did not interfere in the assay.

Single detergent treatment. Prior to an experiment, the frozen microsomes wer thawed overnight at $6^{\circ} \mathrm{C}$. To adjust the protein to the required concentration, the suspension was redispersed with 10 strokes of the pestle in a loose-fitting Dounce homogenizer after adding the appropriate volume of the same buffer in which th membranes were stored (see Table $\pi$, final step). The incubation medium consisted of $3 \mathrm{mM} \mathrm{Na}_{2}$ EDTA, $1 \mathrm{mM}$ dithiothreitol, 
$7.8 \%(\mathrm{w} / \mathrm{v})$ glycerol and membrane protein concentrations of either $0.25,1.9$ or $4.0 \mathrm{mg} / \mathrm{ml}$ with the desired detergent concentration (percent $\mathrm{v} / \mathrm{v}$ ). The buffering of the medium was varied by using either $50 \mathrm{mM}$ Tris-acetate at pH 7.10 or $7.50 \mathrm{mM}$ Tris - acetate at four different $\mathrm{pH}$ values $(6.31,6.87$, $7.10,7.50)$. The particular condition used is indicated with the pertinent results. Complete mixing was achieved by five rapid strokes of the pestle in a loose-fitting Dounce homogenizer. Immediately following incubation, the material was centrifuged at $95000 \times \mathrm{g}$ for $1 \mathrm{~h}$ at $4^{\circ} \mathrm{C}$ in a Beckman Model L-2 ultracentrifuge equipped with either a $50 \mathrm{Ti}$ or an $\mathrm{SW} 27$ rotor.

At a detergent concentration of $0.5 \%$ and a microsome concentration of $1.9 \mathrm{mg} / \mathrm{ml}$ of protein, assay of the supernatant fluid showed that $83 \%$ of the original microsomal $\left(\mathrm{Na}^{+}, \mathrm{K}^{+}\right)$-ATPase activity and $56 \%$ of the protein appeared in the supernatant. Closer examination revealed that the bottom $20 \%$ of the supernatant contained $75 \%$ of the supernatan 1 's $\left(\mathrm{Na}^{+}, \mathrm{K}^{+}\right)$-ATPase activity and $40 \%$ of its protein. Furthermore, the responses in enzyme activity and protein concentration in whole supernatant vs. the lower $20 \%$ of the supernatant were similar over the full range of LOC concentrations employed $(0.05 \%$ to $1.5 \%)$. Serial aliquots taken from the top of the supernatint at LOC treatments of $0.5 \%, 0.7 \%$, and $1.0 \%$ showed that the enrichment was in the lower fraction of the supernatant and not others. Consequently, the lower $20 \%$ of the supernatant was used in the work reported here, and will hereafter be referred to as the sup- 20 fraction.

Sequential treatment. Membranes $(1.9 \mathrm{mg}$ protein $/ \mathrm{ml})$ were treated with $0.25 \%$ detergent as described above. After incubation for $30 \mathrm{~min}$ at $25^{\circ} \mathrm{C}$, the sample was centrifuged at $95000 \times \mathrm{g}$ for $1 \mathrm{~h}$ at $4^{\circ} \mathrm{C}$. The pellet was homogenized in the Tris-EDTA-dithiothreitol buffer shown in the last step in Table I. The resulting suspension was divided into aliquots, and was subjected to treatment with the detergent at different concentrations, while keeping all other conditions the same as above. The samples were centrifuged as before, and the sup-20 fractions were collected and assayed for their specific activity.

Critical micelle concentration $(\mathrm{cmc})$. Surface tension measurements were performed with a Model LG tensiometer made by the Federal Pacific Electric Company. A platinum plate was dipped into volumes of about $10 \mathrm{ml}$ of fluid in a $50 \mathrm{ml}$ beaker. Distilled $\mathrm{H}_{2} \mathrm{O}$, and benzene were used as calibrating standards. After each measurement, the plate was rinsed twice with water and heated to a glowing red in a flame. A zero calibration was made before each sample reading. Plots of LOC concentration (\%) vs. surface tension (dynes $/ \mathrm{cm}$ ) were constructed to determine the $\mathrm{cmc}$. Further details are given in the appropriate figure legends.

\section{RESULTS}

Ionic strength, temperature, and $\mathrm{pH}$ of treatment. The specific activity of the $\left(\mathrm{Na}^{+}, \mathrm{K}^{+}\right)$-ATPase of the untreated microsomal fraction was $34.9 \mu \mathrm{M} \mathrm{P} /$ $\mathrm{mg}$ protein $/ \mathrm{h}$. Treatment of the microsomes with $0.5 \%$ detergent gave $37 \%$ 
higher specific activity when the concentration of Tris-acetate buffer ( $\mathrm{pH}$ 7.10) was $50 \mathrm{mM}$ rather than $7.50 \mathrm{mM}$. Also, incubation of the microsomes with the detergent at $25^{\circ} \mathrm{C}$ gave $213 \%$ higher specific activity than when the detergent treatment was at $6^{\circ} \mathrm{C}$. Curves of specific activity vs. LOC concentration at different $\mathrm{pH}$ values (not shown) revealed that the specific activity was higher over the entire range for $0.3 \%$ to $0.7 \%$ of $\mathrm{LOC}$ for $\mathrm{pH} 7.10$ as compared to 6.31 and 7.50. The peak specific activity at pH 7.10 (see Fig. 1 , middle curve) was $76.1 \mu$ r.oles $P_{1} /$ mg protein/h and was $95 \%$ ouabain-sensitive. The increase in enzyme activity for detergent-treated microsomes may have been due to both purification and activation [11-14]. However, activation was not likely because identical assays were performed on native membranes with detergent added directly to the assay medium (0.05 to $0.55 \%$ LOC) and no increase in specific activity was found over the control samples having no detergent. The yield in total activity (80\% recovery) was greatest at the specific activity peak (Fig. 2, middle curve). The activity of the sup-20
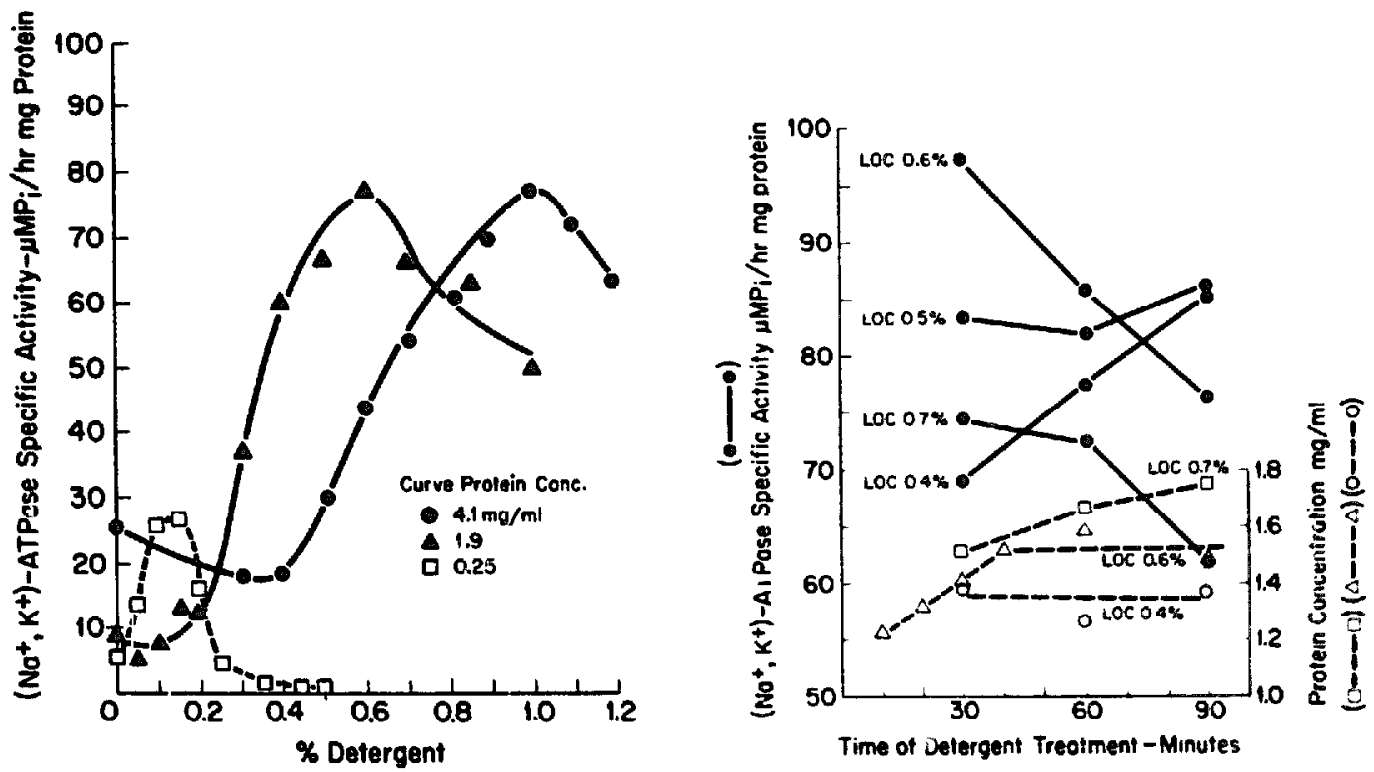

Fig. 1. The effect of protein and LOC concentration on the peak of the $\left(\mathrm{Na}^{+}, \mathrm{K}^{+}\right) \cdot A T P a s e$ specific activity. The incubation media contained 7.5 mM Tris (pH 7.10), $3 \mathrm{mM} \mathrm{Na}$ ATP, $1 \mathrm{mM}$ dithiothreitol, $2 \mathrm{mM} \mathrm{Na}{ }_{2}$ EDTA, and varying concentrations of protein and $\mathrm{LOC}$ as shown in a total volume of $12 \mathrm{rnl}$. The incubations were followed by a 65 min centrifugation at $95000 \times g$. The time of incubations, which were measured from initial mix to placement into a $4^{\circ} \mathrm{C}$ centrifuge hrad, were $30 \mathrm{~min}$ for $1.9 \mathrm{mg} / \mathrm{ml}$ and $45 \mathrm{~min}$ for 0.25 $\mathrm{mg} / \mathrm{ml}$ and $4.1 \mathrm{mg} / \mathrm{ml}$. The sup-20 fraction was assayed.

Fig. 2. The effect of incubation time on $\left(\mathrm{Na}^{+}, \mathrm{K}^{+}\right)$-ATPase specific activity and protein. concentration. The treatment and assay were the same as in Fig. 1 for a protein concentration of $1.9 \mathrm{mg} / \mathrm{ml}$ in the incubation medium. The experiments were designed so as to start the incubations at various times but to quench and centrifuge all samples at the same time. 
fraction was not significantly altered by freezing at $-20^{\circ} \mathrm{C}$ followed by overnight storage and thawing.

Time of incubation. The effect of time of incubation on specific activity is shown in Fig. 2 for four different detergent concentrations. The optimum detergent concentration was found to be $\mathbf{0 . 6 \%}$, for an incubation time of 30 min. Additional time course measurements (data not shown) gave a peak of activity at $30 \mathrm{~min}$ for $0.6 \%$ LOC. The results suggest that with time, the detergent interaction with the membrane first enhances, then inhibits the $\left(\mathrm{Na}^{+}, \mathrm{K}^{+}\right)$-ATPase specific activity. The time course of protein concentration appearing in the sup-20 fraction contrasts remarkably with the time course of the change in the specific activity of the enzyme (Fig. 2). Protein release increases with time to attain a value which depends upon the detergent concentration.

Protein concentration. Fig. 1 also illustrates the effect of varying detergent concentration on the specific activity of $\left(\mathrm{Na}^{+}, \mathrm{K}^{+}\right)$-ATPase obtained at different concentrations of microsomal protein in the incubation mixture. The curve in Fig. 1 for $1.9 \mathrm{mg} / \mathrm{ml}$ represents a 30-min detergent treatment whereas the other curves were for 45 min treatments; when the experiment was repeated for a $30-\mathrm{min}$ treatment from $0.4-0.7 \%$ LOC (see the $30 \mathrm{~min}$ points of Fig. 2) the pattern was similar. The increase in the detergent concentration required for obtaining peak specific activity of the marker enzyme as protein concentration is increased, suggests an alteration in the interaction as the ratio of detergent to protein is varied. Surface tension measurements were therefore made to determine the $\mathrm{cmc}$ at the three protein concentrations. Fig. 3 demonstrates that the $\mathrm{cmc}$ increases as the microsomal protein concentration is increased. The linearity of the curve shows that this increase is proportional to the microsomal protein concentration. This indirectly suggests binding of monomers of LOC to the microsomes. In similar studies, Green [15] used a shift in the cme of Triton X-100, caused by the addition of protein to the detergent solution, to estimate the binding of detergent monomers to the protein, and Kondo et al. [16] used cell lysis to estimate adsorption of nonionic detergents to red cells. For a given protein concentration, Fig. 3 also gives the detergent concentration at which the maximum specific activity of the marker enzyme was observed. This correlates with the presence of micelles.

Sequential detergent treatment. It was noted in plots similar to Fig. 1 that as the detergent concentration was increased, approximately one-third of the total protein was removed before a significant rise occurred in the specific activity of the $\left(\mathrm{Na}^{+}, \mathrm{K}^{+}\right)$-ATPase. Concurrent with this removal of protein there was an increase in the enzyme activity of the remaining microsomal pellet; e.g., when the initial conditions were $1.9 \mathrm{mg} / \mathrm{ml}$ protein, $0.2-0.3 \%$ LOC, an incubation of $45 \mathrm{~min}$ at optimal $\mathrm{pH}$, temperature and ionic strength, there was a 2 -fold increase in the activity.

Therefore, a sequential treatment of the microsomes with the detergent was attempted. The microsomes were first incubated in a low detergent concentration $(0.25 \%)$ to remove non- $\left(\mathrm{Na}^{+}, \mathrm{K}^{+}\right)$-ATPase protein, and then reincu- 

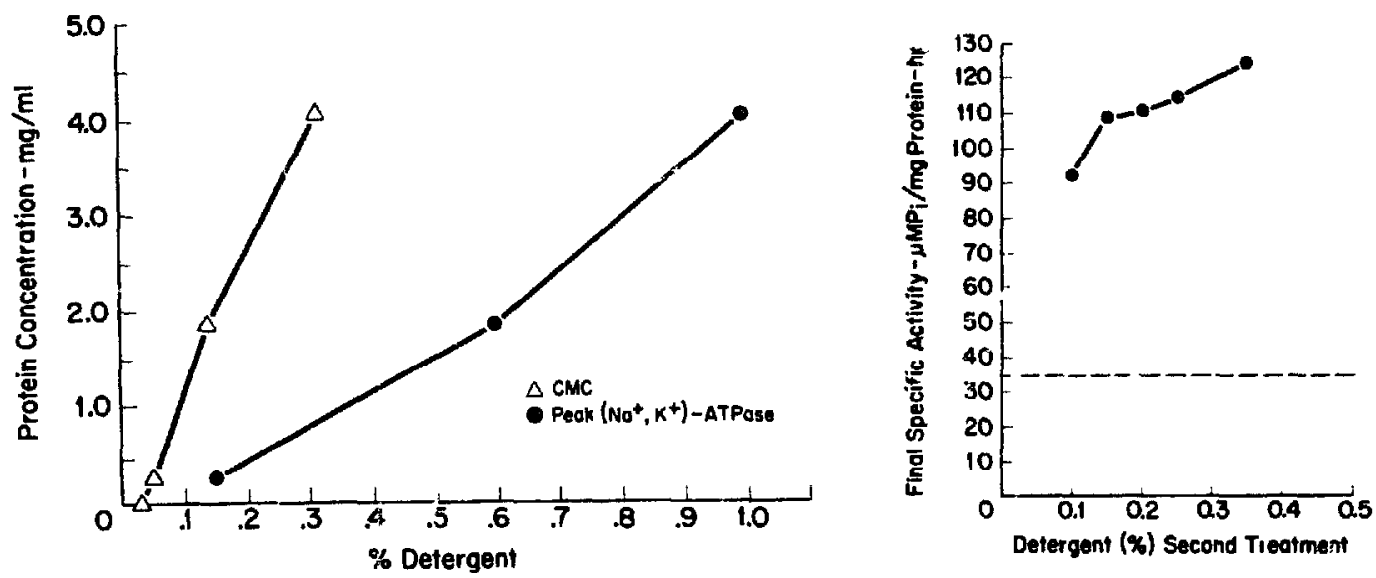

Fig. 3. The effect of protein concentration on the critical micelle concentration (cmc) of the detergent and on tise jetergent concentration required to give maximum $\left(\mathrm{Na}^{+}, \mathrm{K}^{+}\right)$ATPase specific activity. The incubation media were identical to those of Fig. 1. The surface tension of the media was measured at 30 min for each data point on determining the cme.

Fig. 4. Effect of detergent cn pellet remaining after treatment with $0.25 \%$ LUC. The initial detergent concentration was $0.25 \%$. The detergent concentrations in the second treatment are given as the abscissa in the figure. The dotted horizontal line represents the control value for untreated microsomes. The incubation media was the same as in Fig. 1 with indicated concentrations of detergent and $1.9 \mathrm{mg}$ protein $/ \mathrm{ml}$. The time period of both incubations was $30 \mathrm{~min}$ at $25^{\circ} \mathrm{C}$.

bated in a higher detergent concentration while maintaining the optimal conditions for a protein concentration of $1.9 \mathrm{mg} / \mathrm{ml}$ during the latter treatment (Fig. 4). The curve shown may be compared with the middle curve of Fig. 1 which represents the values obtained for a non-sequential treatment but with the same conditions otherwise. For the sequential treatment the highest specific activity of $\left(\mathrm{Na}^{+}, \mathrm{K}^{+}\right)$-ATPase was $124 \mu$ moles $\mathrm{P}_{\mathrm{i}} / \mathrm{mg}$ protein $/ \mathrm{h}(92 \%$ ouabain-sensitive) representing about a 3.5 -fold increase over the untreated $\mathrm{mi}$ crosomal specific activity.

Protein separation from the microsomes. Increasing the $\mathrm{pH}$ of the incubation medium above 6.31 increased the amount of protein in the sup-20 fraction over the range of LOC concentrations as shown in Fig. 5A. These results indicate that the release of protein approaches a maximum at about $\mathrm{pH} 7.10$ and remains essentially constant up to $\mathrm{pH} 7.50$. When the $\left(\mathrm{Na}^{+}, \mathrm{K}^{+}\right)$-ATPase specific activities (not shown) were plotted instead of protein, the responses to these $\mathrm{pH}$ values were quite similar except that the $\mathrm{pH} 7.10$ curve was clearly the highest.

An interesting comparison is shown in Fig. 5B where the proportion of microsomal protein that shifts into the sup-20 fraction during detergent treatment is shown to be dependent upon the concentration of microsomal protein in the incubation medium. The decrease in the proportion of protein as the concentration of microsomes is increased may be partially due to a 


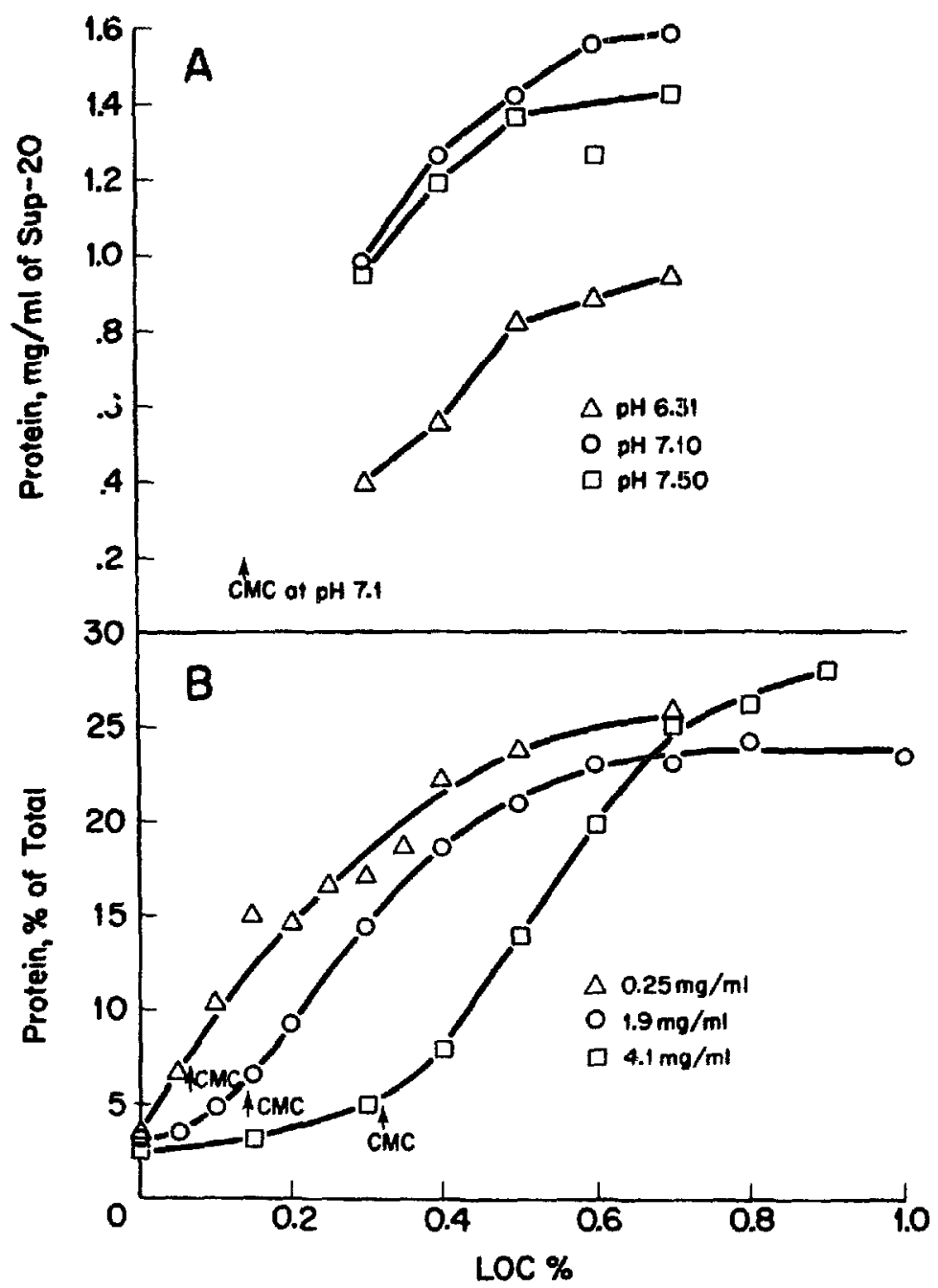

Fig. 5. Response of sup-20 protein to $\mathrm{pH}$, microsome concentration and LOC concentration. Conditions are the same as those for Fig. 2 except that in panel $\mathbf{A}$ the $\mathrm{pH}$ was as indicated. In panel $B$ the total microsomal protein treated was $3 \mathrm{mg}(\Delta), 23 \mathrm{mg}(0)$, and 49 $\mathrm{mg}(\square)$. The percent of this total obtained in the sup.20 fraction is plotted.

time dependency of the action of the detergent. All of the results shown here were for $30 \mathrm{~min}$ incubations. However, as the detergent is increased, the same proportion of the microsomal protein is eventually found in the sup-20 fraction, regardless of the concentration of microsomes in the incubation medium. The response gave sigmoidal curves which may suggest multiple binding sites for the detergent and cooperativity in the binding process $[17,18]$. This was explored further by constructing a Hill plot with the data from the middle curve in Fig. 5B, where the amount of protein in the supernatant and LOC concentration are the two variables as shown in Fig. 6. The curve contains two or three segments with marked differences in the slopes or the Hill coefficient, $n$, near the cmc. 

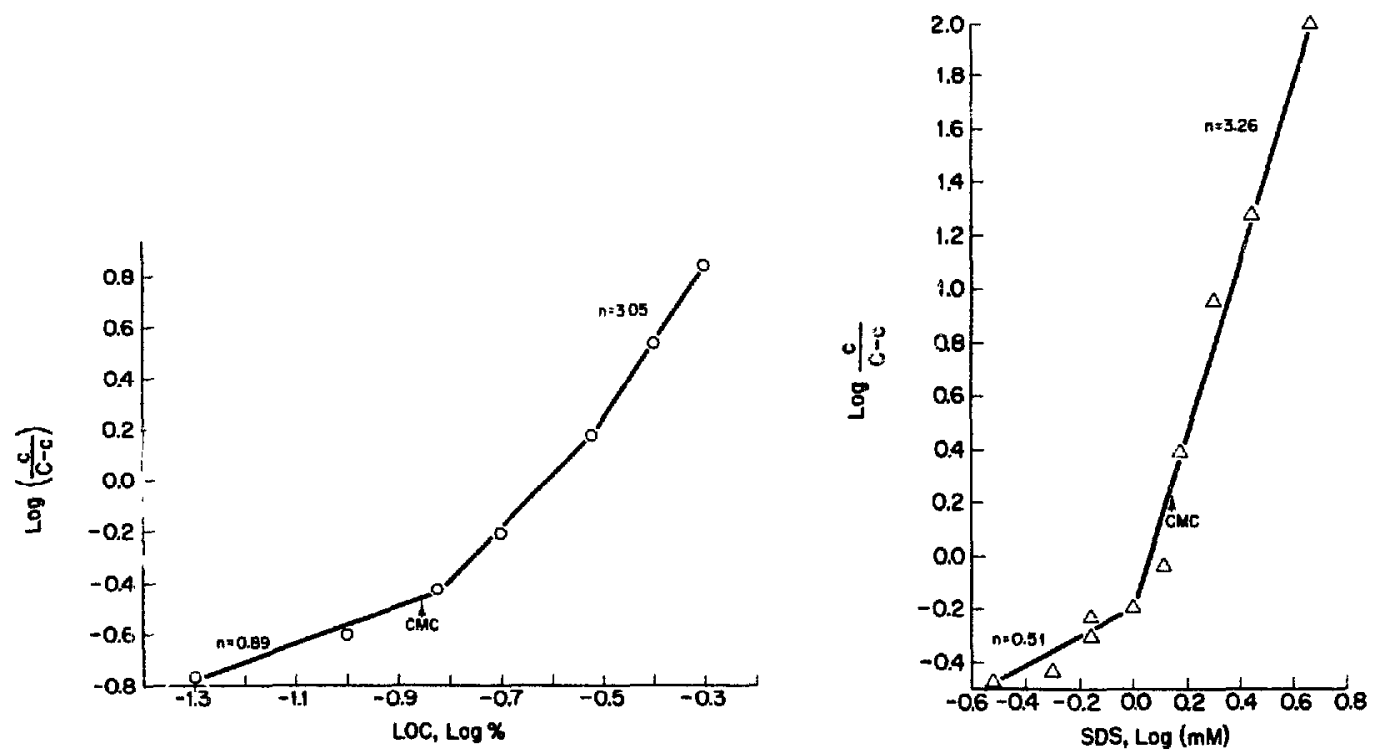

Fig. 6. Hill plot of sup-20 protein with LOC treatment. Data from middle curve $(O)$ for Fig. 5. c, protein concentration, $\mathrm{mg} / \mathrm{ml}$. C, maximal $=24 \%$. The vertical arrow $(\uparrow)$ indicates the r:mc.

Fig. 7. from to panel of Fig. 1 of ref. 2 . c, protein concentration, $\mathrm{mg} / \mathrm{ml}$. C, maximal $=100 \%$. The vertical arrow $(\uparrow)$ indicates the $\mathrm{cmc}$.

Since the average unit size of membrane particle in the supernatant and molarities of the detergent are unknown, we are primarily interested in the relative changes that occurred in the curve. The ratio of $\mathbf{n}$ for the upper segment of the curve to that of the lower segment was 3.43. Since $n$ is expected to be an integer obtained by rounding upward [17], this value suggests that there may be four times as much detergent bound per unit of microsomal protein in the region of the curve above the $\mathrm{cmc}$ as that below the $\mathrm{cmc}$. Similar resulis were obtained when the other two curves in Fig. 5B were plotted as in Fig. 6.

To our knowledge, this type of analysis has not been employed for describing detergent-membrane interactions. Therefore, in order to test its usefulness with a different detergent-membrane system, the data of Kirkpatrick et al. [2] were treated in the same manner (data from their Fig. 1, top panel). A Hill plot of this dodecyl sulfate-red cell membrane study, shown in Fig. 7, gave results similar to those in Fig. 6. However, the ratio of the slopes for the two segments of the curve in Fig. 7 is 6.4 which suggests seven times as much detergent bound above the cmc as below it.

\section{DISCUSSION}

There was a correspondence between the appearance of sup-20 fraction enzyme activity and protein for the two highest microsome concentrations 
under conditions in which only the detergent concentration was varied. There was also a similarity in the response of enzyme activity and protein to changes in $\mathrm{pH}$ over a range of detergent concentrations. These results suggest that $\left(\mathrm{Na}^{+}, \mathrm{K}^{+}\right)$-ATPase could be a marker for the orthogonal $*$ disruption of membranes by detergents if the enzyme is an integral or intrinsic membrane protein $[19,20]$. There is evidence to indicate that it spans the membrane. For example, Kyte [21] observed that antibodies to the whole molecule of the $\left(\mathrm{Na}^{+}, \mathrm{K}^{+}\right)$-ATPase found antigenic sites on both sides of the membrane. Furthermore, antibodies to the purified large subunit of the $\left(\mathrm{Na}^{+}, \mathrm{K}^{+}\right)$-ATPase would bind only to the inside of the membrane. On the other hand, there is evidence that the receptor for ouabain, a specific inhibitor of this enzyme, is located on the outside of the membrane and that the enzyme is closely associated with the receptor [22]. Singer [19] has proposed that membrane transport proteins, including the $\left(\mathrm{Na}^{+}, \mathrm{K}^{+}\right)$-ATPase, contain integral subunit aggregates which span the membrane. On the basis of the evidence available, thus far, this enzyme appears to meet the criteria expected of an integral protein [19].

The sequential detergent treatment showed that other proteins may be removed from the microsomal membranes at low detergent concentrations at or below the cmc. These proteins may be peripheral or extrinsic proteins $[19,20]$. This appears to be an effect similar to that observed by Kyte [23] and Jorgensen [24] where other proteins were removed from microsomal particles, leaving the microsomes enriched in $\left(\mathrm{Na}^{+}, \mathrm{K}^{+}\right)$-ATPase activity. Indeed we noted an increase in the microsomal enzyme activity after an initial treatment at a low detergent concentration.

The literature permits a comparison to be made between the effectiveness of LOC, a binary detergent, and other detergents to stimulate $\left(\mathrm{Na}^{+}, \mathrm{K}^{+}\right)$ATPase activitv. A one-step treatment with LOC followed by centrifugation gave a supernatant $\left(\mathrm{Na}^{+}, \mathrm{K}^{+}\right)$-ATPase activity that was $95 \%$ ouabain-sensitive and 2-fold higher than the untreated microsomes. This compares favorably with methods using monary detergents [12,25-27]. Since the interactions of membrane-bound enzymes with detergents are complex [28], many parameters may be varied in order to find conditions for selectively solubilizing a particular enzyme. Binary detergents may have more capacity for selectively interacting with specific membrane components since the detergent is composed of more than one active agent.

The time of incubation of membrane with detergent showed apparent differences between the release of protein and $\left(\mathrm{Na}^{+}, \mathrm{K}^{+}\right)$-ATPase activity. First, at low detergent concentrations a steady state level of protein was obtained while specific activity was still increasing with time. Second, at higher detergent concentrations, the protein level was either increasing or constant while the specific activity was declining with time. These time curves of specific ac-

\footnotetext{
* We are proposing this term to imply that otherwise intact segments of the membrane would be separated from each other by complete cleavage only in the cross sectional planes; i.e., in a direction that is orthogonal to the plane of the membrane surface.
} 
tivity differ remarkably from those of Jorzensen and Skou [14] while the pattern of protein release is smilar to their time curves of specific activity.

The pattern of enzyme activity with time may have several underlying mechanisms. The continued rise in enzyme activity after the protein has plateaued, as observed at low detergent concentrations, could be due to the removal of a natural inhibitor or regulator from the ATPase complex $[29,30]$ expcsing latent sites [14]. The decline in enzyme activity noted at longer incubation times and higher detergent concentrations may be due to "solubilization" of lipids [2] or other nonenzyme components which may have an inhibitory effect on the ATPase. Ahmed et al. [31] have observed the inhibition of the $\left(\mathrm{Na}^{+}, \mathrm{K}^{+}\right)$-ATPase with fatty acids which proceeds over a time course similar to the incubation times employed in these studies. It is known that fatty acids are a constituent of $\left(\mathrm{Na}^{+}, \mathrm{K}^{+}\right)$-ATPase preparations [32]. Also, the inhibitory effect could be due to an interference of detergent with the interaction of specifically required phospholipids with the enzyme (cf. refs. 12, 27, 33-35), or due to a direct attack on the enzyme by the detergent. The inactivation of the enzyme by some detergents is related to its stabilization by acidic phospholipids while the inactivation by fatty acids and other detergents appears to be unrelated to this stabilization [36].

The plateauing of protein with time suggests that at a given detergent-toprotein ratio, only a limiting fraction of the membrane protein is released. This may be due to a saturation of the detergent which is interacting with the membrane to form stable complexes which cannot further participate in distupting the membrane.

Binding is an important aspect of the interaction between detergents and membranes. Evidence for detergent binding to proteins has been reported by numerous investigators $[1,3,15,16,37-39]$. An example is bovine serum albumin, which binds DOC and Triton X-100 predominantly as monomers $[15,37]$. Below the cme of a detergent only monomers would exist in solution [7]. An increase in the $\mathrm{cmc}$ as the microsomal protein concentration is increased (Fig. 3) would be expected if monomers were bound to the microsomes, since they would be unavailable for micelle formation. The linearity of the cmc curve in Fig. 3 (slope $=0.6$ ) indicates a fixed ratio of detergent to microsomal protein at which micelles begin to form. Above the $\mathrm{cmc}$ there was an increase in both protein and ATPase specific activity. The change in the Hill coefficient indicates that approximately four times (Fig. 6) and seven times (Fig. 7) as much detergent per unit of protein interacts with membranes above the cmc as below it. These results strongly suggest that for both the nonionic detergent, LOC, and the ionic detergent, SDS, micelles participate in the disruption of membranes. This is in agreement with the models proposed by Kondo et al. [3] for the action of both types of detergents upon membranes.

Robinson and Tanford [40] observed that a limited amount of SDS monomers bound to the polar fragment of cytochrome $b_{s}$, a protein purified from membranes. However, the hydrophobic fragment of this protein bound a relatively large amount of SDS in a highly cooperative fashion near the 
cmc, a process interpreted as co-micellization which is tantamount to the incorporation of the hydrophobic portion of the protein into the detergent micelle. The hydrophobic fragment also formed co-micelles with the nonionic detergent Triton X-100. Correlating our observations with those of Kondo et al. [3] and Robinson et al. [40] would indicate that the disruption of membranes by detergents is an ordered sequence of events in which detergent monomers first bind in a limited amount to exposed polar segments of membrane proteins giving rise to openings in the membrane. Then hydrophobic interactions between the detergent and the interior of the membrane lead to co-micellization of the detergent with the hydrophobic portions of the proteins. This should separate fragments of the membrane. Under the stress of a differential centrifugation the co-micelles should more easily float into the supernatant than large fragments of membrane with less detergent bound to it, thus effecting solubilization.

Since both polar and hydrophobic forces would be operative, respectively, in the initial absorption of detergent monomers and in the subsequent comicellization $[1,3,23,37,41]$, the ionic strength and temperature should affect the disruptive process. The increase in $\left(\mathrm{Na}^{+}, \mathrm{K}^{+}\right)$-ATPase activity associated with an increase in the ionic strength and temperature is in agreement with this.

In summary, these observations may at least partially describe how detergents may disrupt membranes and affect membrane bound enzymes. Understanding the nature of the interaction process should increase the potential to specifically direct the action of detergents upon the constituents of biomembranes.

\section{ACKNOWLEDGEMENTS}

This work was supported in part by grants CA-06734 and GM-892 from the National Institutes of Health. We would like to thank Dr. Khalil Ahmed, Minneapolis Veterans Hospital, for carefully reviewing the manuscript and Dr. Kazuya Taniguchi, Hokkaido University, Sapporo, I'dan, for helpful discussions.

\section{REFERENCES}

1 A. Helenius and K. Simons, The binding of detergents to lipophilic and hydrophilic proteins, J. Biol. Chem., 247 (1972) 3656.

2 F.H. Kirkpatrick, S.E. Gordesky and G.V. Marinette, Differential solubilization of proteins, phospholipids, and cholesterol of erythrocyte membranes by detergents, Biochim. Biophys. Acta, 345 (1974) 154.

3 M. Kondo, M. Yoshimura and $T$. Okuyama, Solubilization of bovine erythrocyte membrane by various detergents, Seikagaku, 44 (1972) 849.

4 J. Yu, A. Fischman and T.L. Steck, Selective solubilization of proteins and phospholipids from red blood cell membranes by non-ionic detergents, J. Supramol. Struct., 1 (1973) 233.

5 A. Tzagoloff and H.S. Penefsky, Extraction and purification of lipoprotein complexes 
from membranes, in William B. Jakoby (Ed.), Methods of Enzymology, Vol. 22, Academic Press, New York, 1971, pp. 219-230.

6 M.S. Bretscher, Membrane structure: some general principles, Science, 181 (1973) 622.

7 A. Helenius and K. Simons, Solubilization of membranes by detergents, Biochim. Biophys. Acta, 415 (1975) 29.

8 D.M. Neville, The isolation of a cell membrane fraction from rat liver, d. Biophys. Biochem. Cytol., 8 (1960) 413.

9 R.L. Post and A.K. Sen, Sodium and potassium-stimulated ATPase, in Ronald W. Estabrook and Maynard E. Pullman (Eds.), Methods of Enzymology, Vol. 10, Academic Press, New York, 1967, pp. 762-768.

10 O.H. Lowry, N.J. Rosebrough, A.E. Farr and R.J. Randall, Protein measurement with the Folin phenol reagent, J. Biol. Chem., 93 (1951) 265.

11 L.E. Hokin, J.L. Dahl, J.D. Deupree, J.F. Dixon, J.F. Hackney and J.F. Perdue, Studies on the characterization of the sodium-potassium transport, adenosine triphosphatase, X. Purification of the enzyme from the rectal gland of Squalus aconthios. d. Biol. Chem., 248 (1973) 2593.

12 S. Uesugi, A. Kahlenberg, F. Medzihradsky and L.E. Hokin, Studies on the characterization of the sodium-potassium transport adenosine triphosphatase, IV. Properties of a lubrol-solubilized beef brain microsomal enzyme, Arch. Biochem. Biophys., 130 (1969) 156.

13 R.B. Koch, Biochemical studjes of olfactory tissue: Responses of ATPase activities to octanol and ascorbic acid, Chem.-Biol. Interact., 4 (1971/1972) 195.

14 P.L. Jorgensen and J.C. Skou, Purification and characterization of $\left(\mathrm{Na}^{*}+\mathrm{K}^{*}\right)$-ATPase, I. The influence of detergents on the activity of $\left(\mathrm{Na}^{+}+\mathrm{K}^{+}\right)$-ATPase in preparations from the outer medulla of rabbit kidney, Biochim. Biophys. Acta, 233 (1971) 366.

15 F.A. Green, Interactions of a nonionic detergent, 11 . With soluble proteins, J. Coll. Inter. Sci., 35 (1971) 481.

16 T. Kondo and M. Tomizawa, Hemolysis by nonionic surface-active agents, J. Pharm. Sci., 57 (1968) 1246.

i7 E.A. Dawes, Quantitative Problems in Biochemistry, 5th ed., Williams and Wilkins, Baltimore, 1972, pp. 224-230.

18 H.R. Mahler and E.H. Cordes, Biological Chemistry, 2nd ed., Harper and Row, New York, 1966, pp. 307-309.

19 S.J. Singer, The molecular organization of membranes, Ann. Rev. Biochem., 43 (1974) 805.

20 G. Vanderkooi, Molecular architecture of biological membranes, Ann. N.Y. Acad. Sci., 195 (1972) 6.

$21 \mathrm{~J}$. Kyte, The reactions of sodium and potassium ion-activated adenosine triphosphatase with specific antibodies, J. Biol. Chem., 249 (1974) 3652.

22 A. Schwartz, G.E. Lindenmeyer and J.C. Allen, The sodium-potassium adenosine triphosphatase; pharmacological, physiological, and biochemical aspects, Pharm. Rev., 27 (1975) 3.

$23 \mathrm{~J}$. Kyte, Purification of the sodium- and potassium-dependent adenosine triphosphatase from canine renal medulla, J. Biol. Chem., 246 (1971) 4157.

24 P.L. Jorgensen, Purification and characterization of $\left(\mathrm{Na}^{+}+\mathrm{K}^{+}\right) \cdot \mathbf{A T P}$ ase, III. Purifica tion from the outer medulla of mammalian kidney after selective removal of mem. brane components by sodium dodecylsulfate, Biochim. Biophys. Acta, 356 (1974) 36.

$25 \mathrm{~K}$. Ahmed and J.D. Judah, Preparation of lipoproteins containing cation-dependent ATPase, Biochim. Biophys. Acta, 93 (1964) 603.

26 S.P. Banerjee, I.L. Dwosh, V.K. Khanna and A.K. Sen, Solubilization of quinea pige kidney $\left(\mathrm{Na}^{+}+\mathrm{K}^{+}\right)$-ATPase with Lubrol $W$ and Triton X-100. Biochim. Biophys. Acta, $211(1970) 345$. 
27 D.W. Towle and J.H. Copenhaver Jr., Partial purification of a soluble $\left(\mathrm{Na}^{+}+\mathrm{K}^{+}\right)$dependent ATPase from rabbit kidney, Biochim. Biophys. Acta, 203 (1970) 124.

28 J.K. Dunnick, G.V. Marinette and P. Greenland, Effect of detergents and sodium fluoride on the enzyme activities of the rat liver membrane, Biochim. Biophys Acta, 266 (1972) 684.

29 T. Yamamoto, A factor regulating ATPse activity of the sarcoplasmic reticulum, Ann. Rept. Biol. Works Faculty of Sci., Osaka Univ., 14 (1966) 37.

30 F.J.R.M. Nieuwenhuis, J.A.M. v.d. Drift, A.B. Voet and K. van Dam, Evidence for a naturally occurring ATPase-inhibitor in Escherichia coli, Biochim. Biophys. Acta, 368 (1974) 461.

31 K. Ahmed and B.S. Thomas, The effects of long chain fatty acids on sodium plus potassium ion-stimulated adenosine triphosphatase of rat brain, J. Biol. Chem., 246 (1971) 103.

32 K. Kawai, M. Nakao, T. Nakao and M. Fugita, Purification and some properties of Na, K-transport ATPase, III. Comparison of lipid and protein components of Na, K-ATPase preparations at various purification steps from pig brain, J. Biochem. (Tokyo), 73 (1973) 979.

33 N. Nakao, T. Nakao, Y. Hara, F. Nagai, S. Yagasaki, M. Koi, A. Nakagawa and K. Kawai, Purification and properties of $\mathrm{Na}, \mathrm{K}$-ATPase from pig brain, Ann. New York Acad. Sci., 242 (1974) 24.

$34 \mathrm{~K}$. Tanaka and K.P. Strickland, Role of phospholipid in the activation of $\mathrm{Na}^{+}, \mathrm{K}^{+}$-activated adenosine triphosphatase of beef brain, Arch. Biochem. Biophys., 111 (1965) 583.

$35 \mathrm{~K}$. Taniguchi and $\mathrm{Y}$. Tonomura, Inactivation of $\mathrm{Na}^{+}-\mathrm{K}^{+}$-dependent ATPase by phospholipase treatment and its reactivation by phospholipids, J. Biochem. (Tokyo), 69 (1971) 543.

36 C.W. Sharp, D.G. Hunt, S.T. Clements and W.E. Wilson, The influence of dichlorodiphenyltrichloroethane, polychlorinated biphenyls, and anionic amphiphilic compounds on stabilization of sodium- and potassium-activated adenosine triphosphatases by acidic phospholipids, Mol. Pharmacol., 10 (1974) 119.

37 S. Makino, J.A. Reynolds and C. Tanford, The binding of deoxycholate and Triton X-100 to proteins, J. Biol. Chem., 248 (1973) 4926.

38 J. Steinhardt, N. Stocker, D. Carroll and K.S. Birdi, The non-specific large binding of amphiphiles by proteins, Biochemistry, 13 (1974) 4461.

39 S. Uesugi, N.C. Dulak, J.F. Dixon, T.D. Hexum, J.L. Dahl, J.F. Perdue and L.E. Hokin, Studies on the characterization of the sodium-potassium transport adenosine triphosphatase, VI. Large scale partial purification and properties of a lubrol-solubilized bovine brain enzyme, J. Biol. Chem., 246 (1971) 531.

40 N.C. Robinson and C. Tanford, The binding of deoxycholate, Triton X-100, sodium dodecyl sulfate, and phosphatidylcholine vesicles to cy tochrome $b_{5}$, Biochemistry, 14 (1975) 369.

41 T. Kondo and M. Tomizawa, Mechanism of hemolysis by cationic surface-active agents, J. Pharm. Sci., 58 (1969) 1378. 